ENTREPRENEURSHIP AND SUSTAINABILITY ISSUES

ISSN 2345-0282 (online) http://jssidoi.org/jesi/ 2021 Volume 9 Number 1 (September)

http://doi.org/10.9770/jesi.2021.9.1(11)
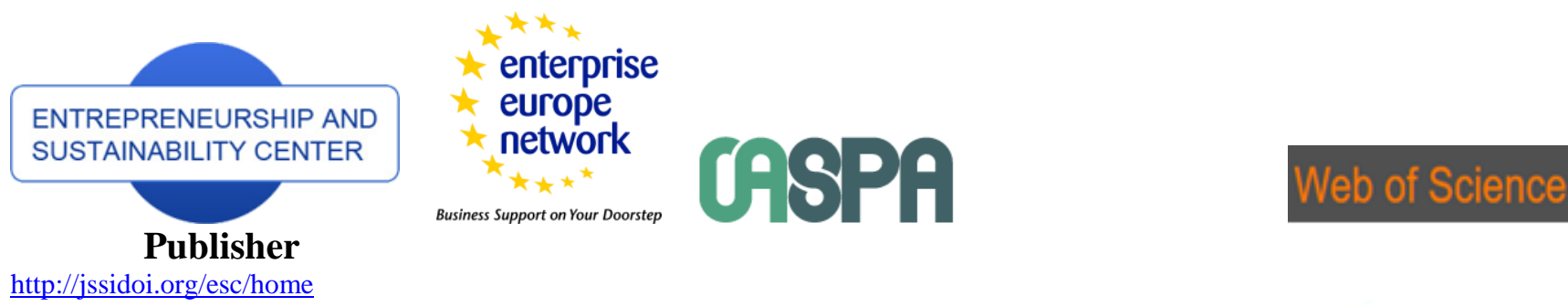

http://jssidoi.org/esc/home

1 Clarivate

Analytics

\title{
CUSTOMER SERVICE QUALITY MANAGEMENT ON THE COURIER SERVICES MARKET ${ }^{*}$
}

\author{
Adam Marcysiak \\ Siedlce University of Natural Sciences and Humanities, Faculty of Social Science, \\ Konarskiego 2, 08-110 Siedlce, Poland \\ E-mail: adam.marcysiak@uph.edu.pl
}

Received 15 March 2021; accepted 8 June 2021; published 30 September 2021

\begin{abstract}
The purpose of the study is to evaluate the quality management of customer services. The paper demonstrates the results of own research on the quality standards of customer services in courier service companies. The significance of the aspects of sustainable development implemented by courier companies for customers was also analyzed. The investigations focused on a group of individual customers availing of the services of courier service companies. The study was conducted in September 2020 with the application of electronic tools in the form of an online survey. The questionnaire was composed of single-choice and multiple-choice questions. Upon a factual and logical verification, 260 surveys were selected for further analysis. The conducted study demonstrates that the prime motives behind the choice of a courier company are delivery completion time, service prices, and safety concerns. The last issue has been particularly crucial amidst the Covid-19 coronavirus epidemic. Over three-fourths of the studied subjects (75.8\%) said they felt safe in contact with courier operators. The door-to-door (D2D) segment is gradually absorbed by PUDO (pick up drop off) and automated package machines. This may, as a consequence, lower the cost of the last mile and increase customer satisfaction. An important element in the activities of courier companies are also aspects of sustainable development. It is about reducing the negative impact on the natural environment. For over half of the respondents (52.7\%), ecological aspects are important or very important. As a result, the most modern companies invest in hybrid and electric cars, optimize travel routes to the customer, and use recyclable packaging. This translates into a better reputation of the company and is also associated with corporate social responsibility.
\end{abstract}

Keywords: customer service; courier services market; quality management; sustainable development; logistics costs

Reference to this paper should be made as follows: Marcysiak, A. 2021. Customer service quality management on the courier services market. Entrepreneurship and Sustainability Issues, 9(1), 190-203. http://doi.org/10.9770/jesi.2021.9.1(11)

JEL Classifications: L22, L26, O32, Q55, Q56

Additional disciplines: management and quality

\footnotetext{
* This research was carried out under the research theme No. 88/20/B financed from by a science grant provided by the Ministry of Science and Higher Education of Poland.
} 


\section{ENTREPRENEURSHIP AND SUSTAINABILITY ISSUES}

ISSN 2345-0282 (online) http://jssidoi.org/jesi/

2021 Volume 9 Number 1 (September)

http://doi.org/10.9770/jesi.2021.9.1(11)

\section{Introduction}

Differences in the quality of customer services constitute vital elements of competitive advantage of enterprises. Strong pricing competition results from market saturation with products in almost every branch. For the majority of customers, customer service quality is the underlying argument when making the purchasing decision (Kempny, 2001).

The contemporary economic reality targets individual customer's need satisfaction. The process of management of the customer service quality captures the process of buying-selling, the complex and competitive after-sales services, and continuing marketing contacts with the consumer - the buyer. Adequately performed customer services should ensure fast, reliable, punctual, timely, and flexible product supplies to purchasers (Długosz, 2005).

All of the mentioned aspects are the characteristic features of the market of courier services. Courier companies aim at reducing delivery times, cutting transport costs, and meeting the requirements of individual clients. Customer care is highly valued due to the fact that the cost of acquisition of a new customer is many times higher than the cost of retaining an existing one. (Song et al., 2018).

The introduction of optimum management of the quality of customer services in the line of courier services has allowed for a flexible response to changes in the demand and adjustment to consumer needs (Zhang et al., 2011). The present market of courier transport is highly diversified with respect to provided services, depending on the market sector. Operators are committed to the comprehensive nature and flexibility of services through the implementation of novel, innovative solutions (Barlow, \& Stewart, 2014).

The market of courier services is the sector of the market of logistics services that features high growth dynamics. Courier services have been gaining importance because of the continuing evolution of the electronic trade. Operators cooperate, above all, with the B2B market. At the same time, there is a rise in the share of the B2C market (Vrontis et al., 2017; He et al., 2019).

In Poland, we can observe an increase in courier branch-related infrastructural investment . State-of-the-art industrial warehouses are mushrooming, terminals and automatic sorting plants are developing (Yu et al., 2020). Moreover, we are witnessing the process of consolidation of courier service companies through the merging of global and national logistics integrators, and large business concerns taking over local service providers (Rydzkowski, 2011).

The offer of courier service companies is highly diversified in terms of quality and pricing. Customers may choose an option for their courier parcels to be delivered within a specific timeframe. Present challenges and threats on the part of competition have become an impulse for courier operators to facilitate the process of customer service quality management through an introduction of a broader service offer and diversification of one's operations (Liu et al., 2018).

In the area of courier companies' activities, the aspects of sustainable development are becoming more and more important. This applies to the limitation of the use of foil packaging, envelopes with bubble foil as a filler, or the external dimensions of the package. Combining environmentally friendly, recycled or biodegradable packaging with less resources can help reduce pollution and harmful materials. Improving your packaging not only reduces your company's carbon footprint, it can also help you differentiate your brand among your customers and further reduce logistics costs. 


\section{ENTREPRENEURSHIP AND SUSTAINABILITY ISSUES}

ISSN 2345-0282 (online) http://jssidoi.org/jesi/

2021 Volume 9 Number 1 (September)

http://doi.org/10.9770/jesi.2021.9.1(11)

\section{Literature review}

The operation of markets in the globalization era has a significant impact on the method of generation of companies' competitive edge. Nowadays, customers expect the product to be practicable, also in terms of place and time, and the orders to be completed on time (Shah, 2020). In practice, this means that customer services focus on the identification of buyers' needs, preferences, and motives behind their purchases, and on need satisfaction. Another vital aspect is development of long-term relations with consumers (Li et al., 2020).

Good management of customer services may be defined as the provision of a suitable product to the customer in accordance with the logistics 7R rule. In other words, the right product must be at the disposal of the customer in the right place and at the right time. (Thirumalai \& Sinha, 2005). Given the above, customer services translate into punctual, certain, reliable product deliveries compatible with relevant orders. According to S. Kauf and A Tuczak, logistics customer services involve the ability of the logistics system to provide a smooth and effective practicability of the place and time in the process of product movement between the seller and the buyer (Kauf, \& Tłuczak, 2018).

On the other hand, customer services may also be viewed from the functional, executive and process perspectives. The process approach has the most advanced scope. It captures the planning, organizing, and supervising the entire cycle of order placement, customer relations, information services and supplies (Palese \& Usai, 2018). The efficiency of customer services determines company's image and the way it is viewed by its competition. The basic assessment criteria are customers' feelings and sensations cited in survey studies.

The growth in the importance of customer services means that it consumes more and more of organizations' resources. The process of decision taking is three-phased: pre-transaction, transaction, and post-transaction. From the logistics point of view, the most essential are the components of the transaction phase, involving the physical product's flow, availability, the cycle of order processing, information regarding the order, and reliability of supply (Naccache \& Montreuil, 2015).

The key element of the transaction phase is time, associated by customers with the delivery timeframe. The processing time acceptable by the customer may be achieved thanks to efficient management (Zuo et al., 2013). The shorter the order completion time, the more satisfied the customer. As a consequence, the customer is likely to consider another purchase and become one's royal customer (Nadeem et al., 2020).

Yet another component of the transaction phase of customer service is reliability. It is understood as the ability to keep agreed deadlines and meet order standards. Reliability further means a damage-free product on delivery. Preciseness and quality of supply are the underlying criteria of customer services (Liang et al., 2019).

The process of communicating with the customer allows one to control order processing. A typical activity, wellassessed by the customers, is the provision of ongoing updates about the stage of order completion and any potential delays. Effective communication system allowing the tracking of parcels is the condition of establishing long-lasting relations with customers. The monitoring of order processing and early information about any potential difficulties or impediments facilitates swift response and allows one to offer satisfying solutions. This is of utomost importance in the event of action undertaken on the market of courier services (Kramarz, 2014).

The next relevant element of the transaction phase is convenience. It consists in flexibility of order completion corresponding to customer's needs (Golmohammadi et al., 2020). In the area of courier service operations, this boils down to the ability to select the time and place of parcel pick-up, and the availability of different methods of order placement and payment. The emphasis on the satisfaction of the customer and his needs has become the main 


\section{ENTREPRENEURSHIP AND SUSTAINABILITY ISSUES}

ISSN 2345-0282 (online) http://jssidoi.org/jesi/

2021 Volume 9 Number 1 (September)

http://doi.org/10.9770/jesi.2021.9.1(11)

challenge of contemporary organizations. This is because a satisfied customer will return and repurchase, or even recommend a product or service to other customers (Rita et al., 2019).

The term courier services has its genesis in postal services. The reason why the sector has been separated was the imperfectness of operation of the national postal companies and low quality of provided services (Liao et al., 2006). Courier operators have competitive advantages thanks to various factors, such as short delivery times, the emphasis on customer's convenience, and reliability in package delivery (Rydzkowski, 2011; Vinodhini \& Chandrasekaran, 2014).

The situation on the market pushed courier service companies to be flexible in meeting their customers' expectations. Nowadays, many companies offer world-wide services, meeting top quality customer service standards. The operators on the market of courier services more and more often operate on the basis of extensive distribution networks, modern sorting plants and terminals (Vakulenko et al., 2018). While striving at the continual improvement of provided service quality, companies offering courier services are trying to suit the scope of activities to the needs of individual customers (Lou et al., 2020).

Given the ongoing transformations, courier operators have become faster in adjusting their offers to customer needs. This pertains to, in particular, parcel management. Recipients (addressees) are able to redirect the parcel to a different address, change delivery dates, even time-frames, and order parcel pick-up within the operator's network (Schwerdfeger \& Boysen, 2020). In addition, some operators of courier services have introduced the standard of package delivery in the late afternoon or evening, or provide couriers' details and phone numbers (Alsaad \& Taamneh, 2019).

What is more, seeing how popular smartphones have become, courier companies have started to launch mobile applications. Thanks to the applications, one can monitor the parcel status, check the location of the collection point and delivery time, or modify them, from any point on Earth (Lemke et al., 2016).

Simultaneously, given the growing expectations of the customers with respect to managing delivery pick-up times, the rising costs, including the cost of labor, the courier market operators have begun a dynamic development of pick-up points. Currently, apart from the ability to collect parcels at company branches, postal establishments or via automatic devices, one may have them delivered to partner networks, such as shops, news stalls or gas/fuel stations (Iwan et al., 2016).

As far as a few years ago, parcels in the courier sector were delivered mainly in the "door to door" (D2D) system. With a shared commitment to improve the quality of customer service standards, courier service companies faced a new challenge in the form of parcels ordered online by individual customers, often out of homes in the courier working hours or based in hard-to-reach locations. The above contributed to the development of deliveries to collection points other than homes or workplaces (D2P - door to point, $\mathrm{P} 2 \mathrm{P}$ - point to point). The system features deliveries to automated package machines and pick-up and drop-off points (PUDO - pick up drop off). In the year 2018, over 13\% of parcels reached PUDOs. The popularity of such delivery forms has been growing annually (Janjevic \& Winkenbach, 2020).

There is a customer service quality management gap in the currently available literature during the Covid-19 coronavirus epidemic. This situation makes it necessary to adapt to new requirements both on the part of companies providing courier services and companies cooperating with them. 


\section{ENTREPRENEURSHIP AND SUSTAINABILITY ISSUES}

ISSN 2345-0282 (online) http://jssidoi.org/jesi/

2021 Volume 9 Number 1 (September)

http://doi.org/10.9770/jesi.2021.9.1(11)

\section{Materials and methods}

The purpose of the study is to evaluate the quality management of customer services. This has been illustrated by the case of the courier services market. The conducted research and analysis will significantly contribute to a better understanding and understanding of customer expectations resulting from functioning during the COVID-19 coronavirus epidemic. This can be a useful source of information to develop effective strategies for the operation of companies providing courier services and business units cooperating with them.

Companies in the courier service industry should pay particular attention to the provision of top standards of customer services. In the contemporary economic reality, a satisfied customer is the main source of competitive advantage.

The paper demonstrates the results of own research on the quality standards of customer services in courier service companies. The significance of the aspects of sustainable development implemented by courier companies for customers was also analyzed. The investigations focused on a group of individual customers availing of the services of courier service companies. The conducted surveys were anonymous and voluntary. The criteria of respondent selection were the use of courier service companies and the willingness to complete the questionnaire. The study was conducted in September 2020 with the application of electronic tools in the form of an online survey. The method of conducting the research resulted from the sanitary limitations related to the COVID-19 coronavirus epidemic. It eliminated the traditional form of research.The questionnaire was composed of singlechoice and multiple-choice questions. Some questions offered an option of providing an individual answer. Upon a factual and logical verification, 260 surveys were selected for further analysis.

The studied group was diversified in terms of sex, age, education, and place of residence. The most numerous groups were people aged 18 to 25 and 26 to 35. They made up $36.9 \%$ and $31.9 \%$ of all the respondents, respectively. The remaining age groups, i.e. $36-45$ and 46 and over were much less populous (17.7\% and $13.5 \%$, respectively). This was a consequence of the fact that courier services are mostly used by young people. The respondents varied also in terms of sex. The majority of the surveyed were males. They accounted for $54.6 \%$ of the studied population.

Another differentiating factor was the level of education. The dominant group in the education structure were those who held a degree of higher education and those who were pursuing a degree course (who entered higher education) (32.7\% and 21.9\%). Their total share in the studied population was $54.6 \%$. A relatively large group of respondents was general or vocational high school graduates $(28.5 \%)$. By far the smallest groups of respondents were those who completed basic vocational, elementary school, or junior high school education (16.9\%).

The analysis of the respondents by their place of residence showed that the vast majority lived in the cities $(71.9 \%)$ rather than in the countryside. About one-third (34.2\%) of the respondents came from cities with a population below 100,000, whereas $15.8 \%$ lived in the cities with a population of between 100,000 and 500,000. The remaining group (21.9\%) were city-dwellers who resided in cities with a population exceeding 500,000.

\section{Results and disscussion}

The conducted research study demonstrates that the majority of the studied population (54.6\%) uses courier services several times a month. The 'once a month' option was selected by $28.5 \%$ of the respondents. Only $16.9 \%$ of the respondents avail of courier services several times a year. This diversification is a consequence of individual needs and preferences. 


\section{ENTREPRENEURSHIP AND SUSTAINABILITY ISSUES}

ISSN 2345-0282 (online) http://jssidoi.org/jesi/ 2021 Volume 9 Number 1 (September) http://doi.org/10.9770/jesi.2021.9.1(11)

The major reason behind the use of courier services according to the study participants is the supply of goods purchased online. The respondents specified the types of packages they most frequently order. In this case, they could select more than answer, for they had a few categories of parcels to choose from. Most often (76.5\%) the respondents pointed at packages with apparel and shoe-wear. The next most popular types of packages $(68.8 \%)$ were those containing electronic devices (phones, television sets, laptop computers, etc.) and household articles. Quite popular were also cosmetics and chemical products, spare parts and car accessories, and books (14.6\%, $12.8 \%$ and $9.4 \%$, respectively). The other reasons behind using courier services were shipment of documents $(10.2 \%)$ and items sold online (13.3\%).

Among courier service companies, the absolute leader in the group of individual customers was DPD, whose services were used by as many as $89.6 \%$ of the respondents. DPD was followed by DHL, as selected by over a half of the studied population (76.5\%). Such good results may indicate high level of trust and efficiency of the two logistics operators. The popularity of DPD and DHL is due to the fact that both are the top well-known courier companies on the Polish market of courier transport. The third position is occupied by InPost. The company is the youngest operator on the Polish market of couriers, express parcel delivery and parcels. Above all, it is known of its flagship product - the automated parcel machine or package locker. According to data of the end of January 2021, there were 11,000 such machines in Poland. InPost provides services mostly to individual and institutional customers, focusing on e-commerce, in particular on the logistics operation of APMs and courier services for online shoppers. The company employs 8,000 employees and partners. Nearly a half of the respondents $(46.7 \%)$ have cooperated with InPost.

Poczta Polska has turned out to be equally popular on the Polish market of courier services $(34.8 \%$ of those surveyed). Poczta Polska is a state-owned company with 460 years of tradition, which fulfills the function of an operator obliged to provide common postal services. What is more, it offers parcel and package postal services, and courier and logistics services. The development of the market of couriers, express parcel delivery and parcels and e-commerce is one of the main areas of activity included in the strategy of Poczta Polska. The other courier service companies on the list are: GLS, UPS and FedEx. In the case of these entities, the quantity of indications among the respondents did not exceed $20 \%$.

The respondents were further asked to describe their motives behind choosing a given courier company. Here, also more than answer could be provided. The results are presented in Figure 1.

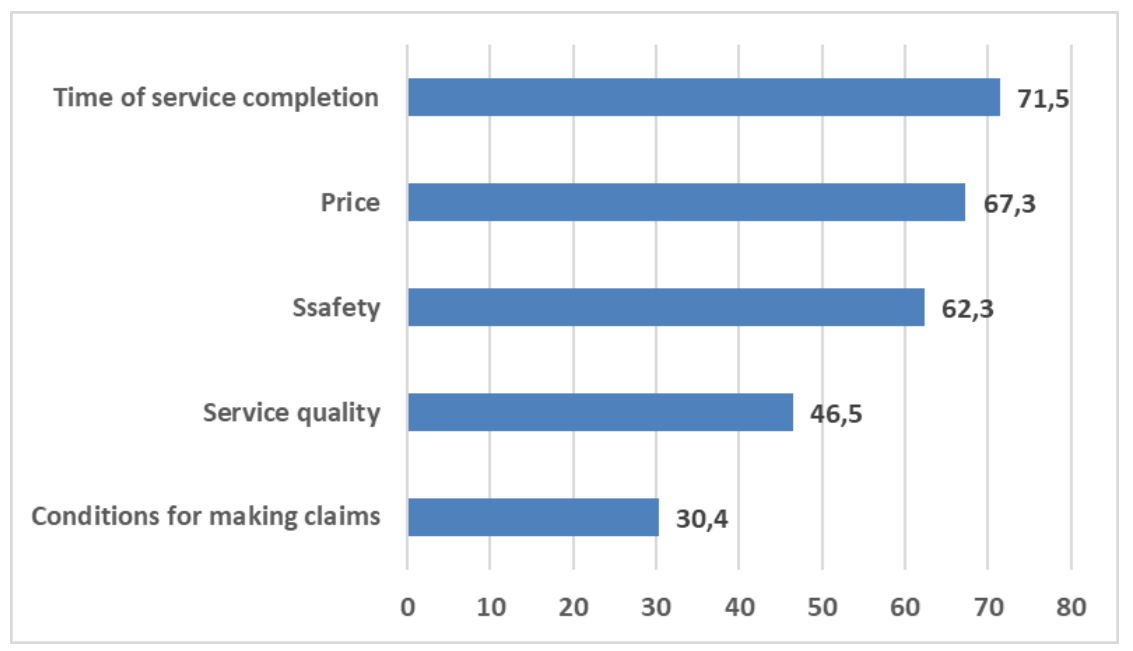

Fig. 1. Things considered when choosing a courier company Source: compiled on the basis of own research 
The absolute majority of the respondents $(71.1 \%)$ paid attention to the time of delivery. This is the most important factor considered when selecting a courier company. Another significant element was the price of services $(67.3 \%)$. It is essential especially for frequent courier service users. Yet one more central reason was safety $(62.3 \%)$. On the one hand, safety was associated with a lack of damages to parcels in transit. On the other hand, it was related to ability to deliver a package to the parcel machine or a fixed pick-up point (PUDO). The latter was particularly popular in the Covid 19 coronavirus epidemics. The quality of services, mostly expressed as timely delivery and custom-made services, was selected by $46.5 \%$ of the respondents. The relatively least frequent motive underlying the choice of a courier company were the conditions for making claims $(30.4 \%)$.

Next, the respondents had an opportunity to evaluate individual components of customer service quality. They could do so on a scale from 1 to 10. Figure 2 presents average ratings of the studied group of customers.

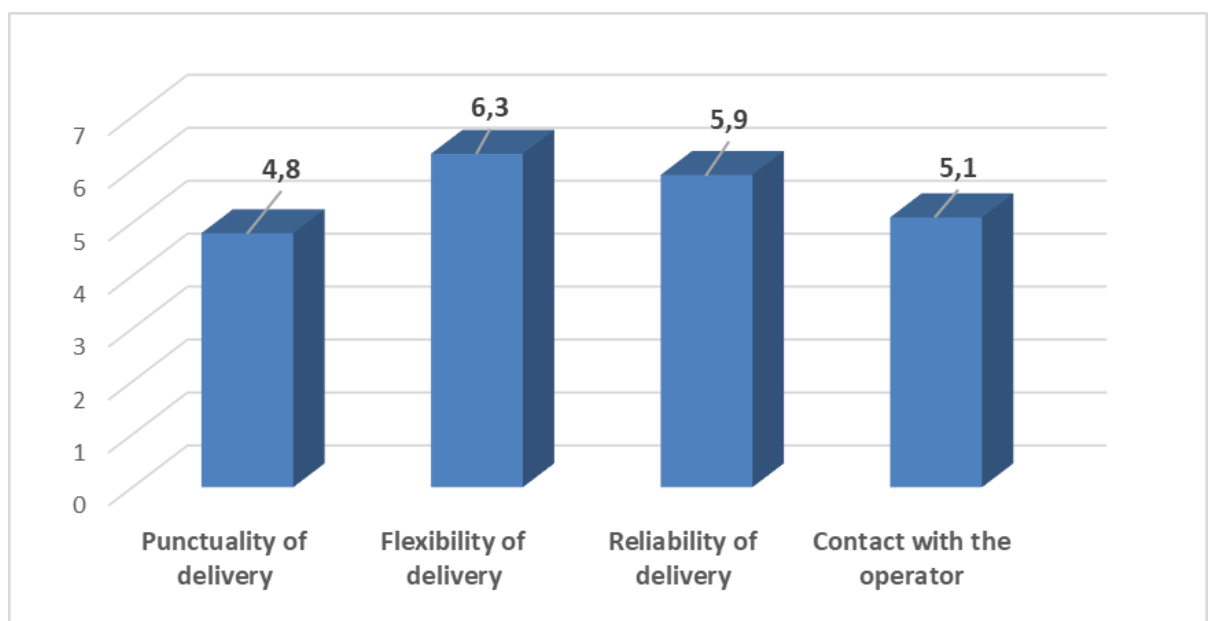

Fig. 2. Distribution of answers regarding the rating of individual elements of customer service Source: compiled on the basis of own research

Courier service users best rated flexibility of deliveries. It consists in the ability to change the dates and address of delivery and tailor to individual customer's needs. The average rating here was 6.3. Reliability of deliveries was, on average, rated quite similarly (5.9). The issues which require greater commitment on the part of courier companies are communication between the operator and the customer, and those related to timely deliveries (date and hour punctuality). The average ratings here were 5.1 and 4.8, respectively, on a scale from 1 to 10 .

The factor which differentiated the respondents was the popularity of the forms of order placement (Figure 3). 


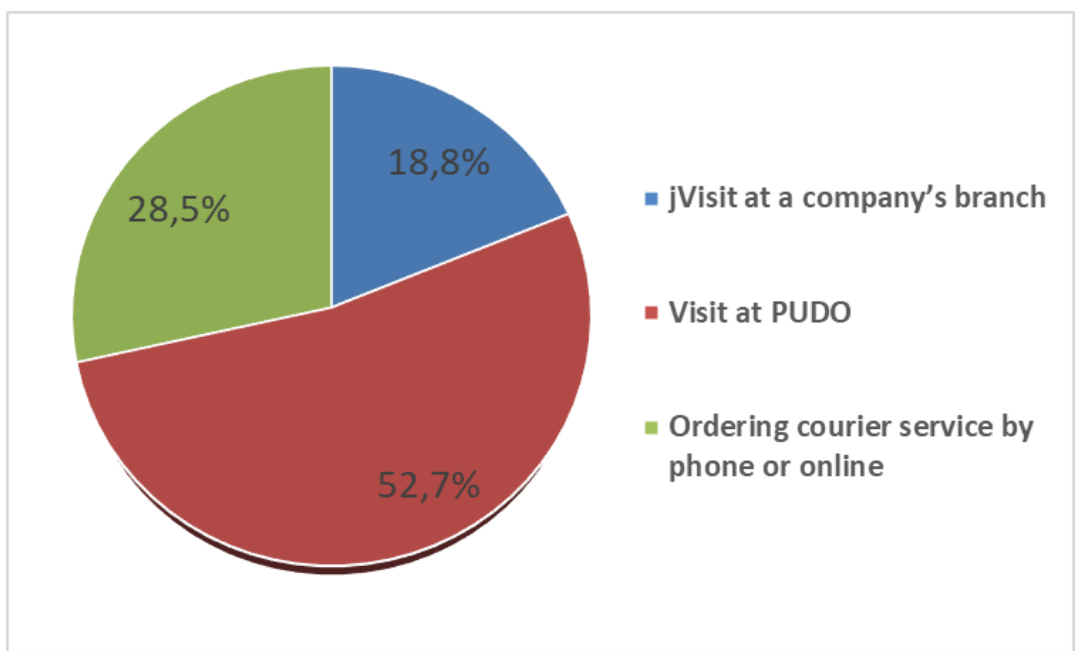

Fig. 3. Distribution of answers regarding the most frequently selected forms of order placement Source: compiled on the basis of own research

When sending a parcel, customer most willingly selected a visit at a PUDO (52.7\%). Beforehand, they used an online form downloaded from a website of a courier operator. The major reasons behind it are comfort, common access, and convenient working hours, often stretching beyond courier working hours, and low cost of communication. A vital issue is to place all information required to place an order on the website of an operator (Patil \& Divekar, 2014). Thanks to electronic forms or direct contact by phone, one can order a courier without even leaving home. This form of communication was indicated by $28.5 \%$ of the respondents. The least popular form of order placement turns out to be a visit at a company's branch office. Customers who continue to highly value direct contact with the service seller constitute only $18.8 \%$ of the group.

The respondents were also asked to mark their level of satisfaction with the components considered when choosing a courier service, i.e. completion time, price and safety. Figure 4 shows the level of satisfaction of the respondents with courier service completion time.

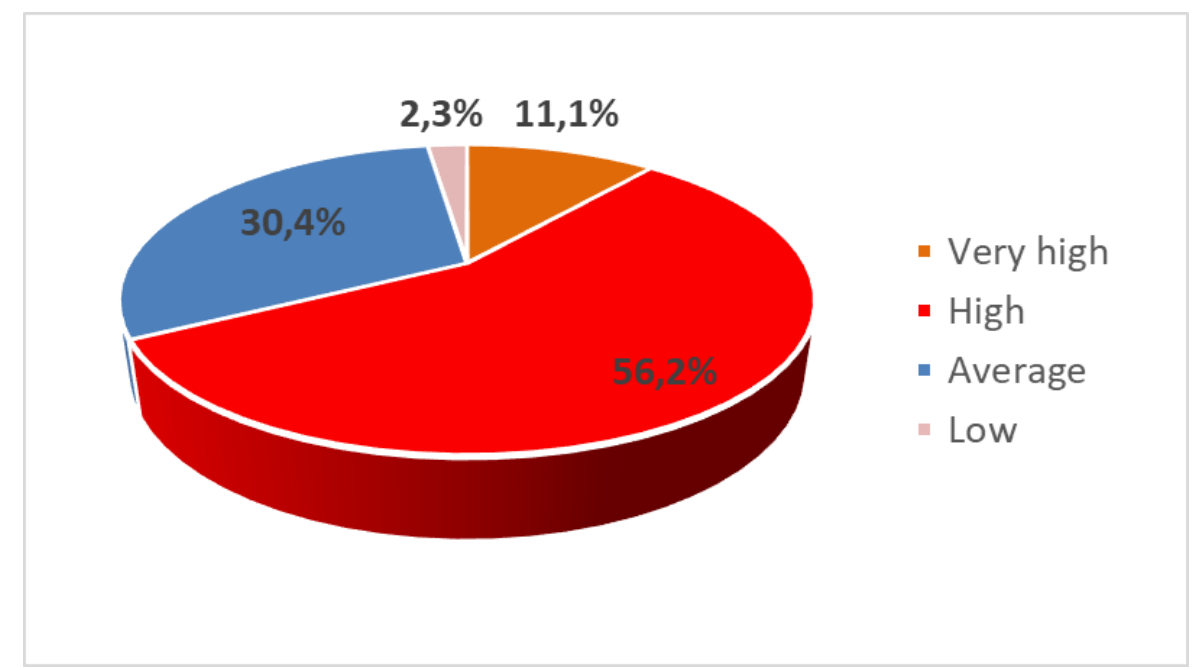

Fig. 4. Level of customer satisfaction with courier service completion time Source: compiled on the basis of own research 
The level of respondents' satisfaction with the time of completion of a courier service is definitely positive. Most of the respondents highly rated the delivery completion time (56.2\%). About eleven percent (11.1\%) expressed their satisfaction level as very high. Average satisfaction levels were indicated by $30.4 \%$ of the studied group. The research findings presented in Figure 4. demonstrate that the time of completion of a courier service, which is the major component considered when choosing a courier operator, is equally highly valued among the respondents. Only $2.3 \%$ of the analyzed persons had a negative opinion. The second most important motive when selecting a courier company was the price of service performance. Figure 5 shows the results of the analysis in respect of the above.

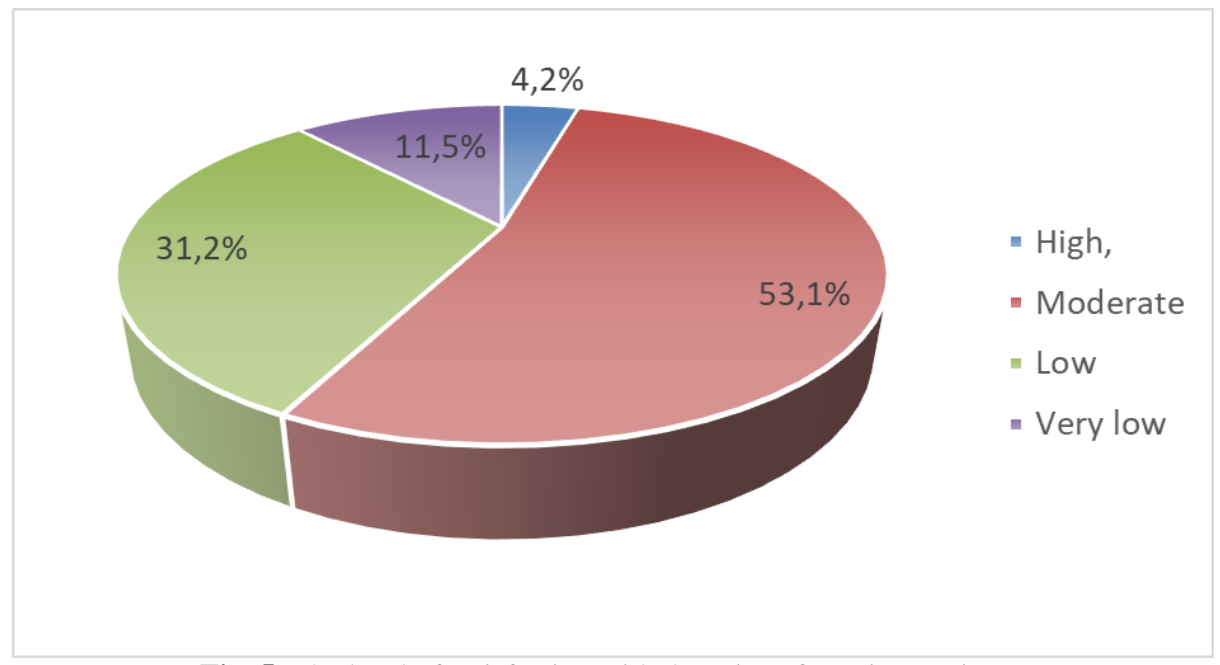

Fig. 5. The level of satisfaction with the price of courier services Source: compiled on the basis of own research

The level of satisfaction with the price of courier services is not as positive as in the case of completion time. The majority of the studied subjects $(53.1 \%)$ were moderately satisfied with the prices of courier services. Nearly every third respondent (31.2\%) expressed a low level of satisfaction with the offered prices. Highly dissatisfied with the pricing levels were $11.5 \%$ of the respondents. Only for $4.2 \%$ of the studied group, the pricing level was suitable. The selection of courier companies was based on the safety of delivery and, above all, package's perfect condition on arrival. The opinions in this respect were also diversified (Figure 6.).

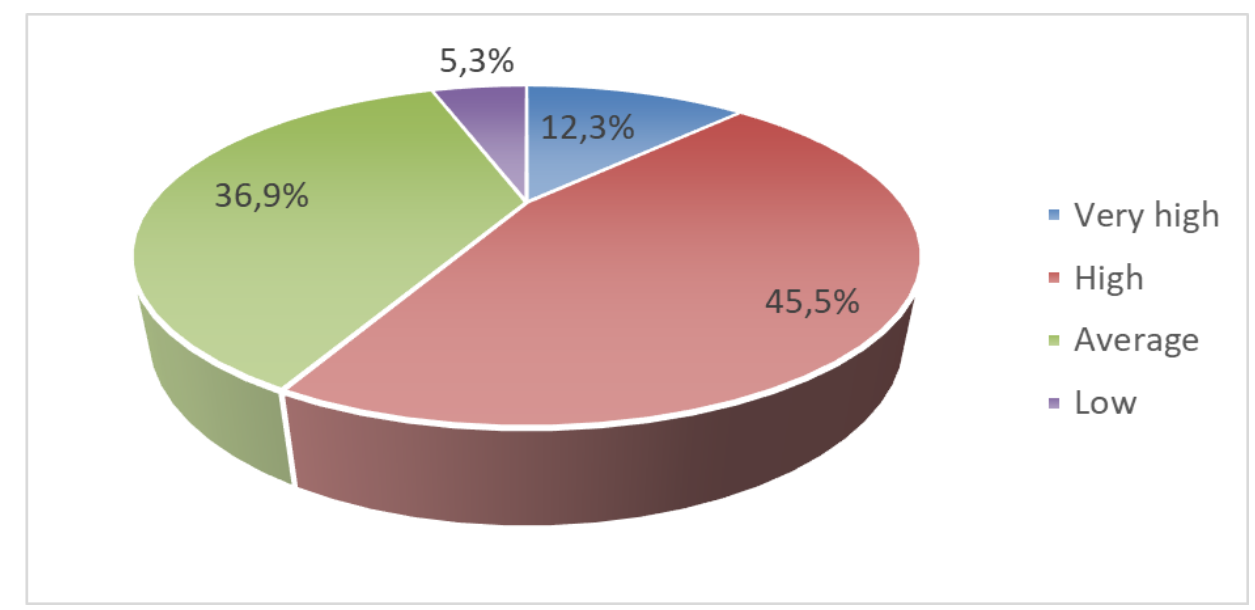

Fig. 6. Level of respondents' satisfaction with the safety of delivered packages Source: compiled on the basis of own research 
The level of safety of delivered parcels was evaluated by the majority of the respondents as high (45.5\%) and very high $(12.3 \%)$. Over one-third of the respondents (36.9\%) expressed a moderate level of satisfaction. Only $5.3 \%$ of the respondents were greatly concerned with the safety of delivered packages.

In the study, the studied subjects were asked to provide information and rate the level of safety of courier services during the COVID-19 pandemic. The first coronavirus case in Poland was detected on 4 March 2020. Since then, the working conditions for courier companies and the whole economy have transformed dramatically. The study participants were asked to provide their rating of the safety principles when contacting a courier company. Over three-fourths of the studied population $(75.8 \%)$ said they felt safe. Courier companies were fast and effective to introduce the basic rules of safe customer contact. For nearly every fifth person $(19.3 \%)$, the epidemic-related threats sensed by the respondents were high but possible to be accepted. Only $4.9 \%$ of the surveyed were anxious about epidemiological threats. Despite the above, however, they show that the use of automated parcel machines can largely decrease health-related risks.

The distribution of answers regarding preferred forms of parcel delivery by courier service companies' customers are shown in Figure 7.

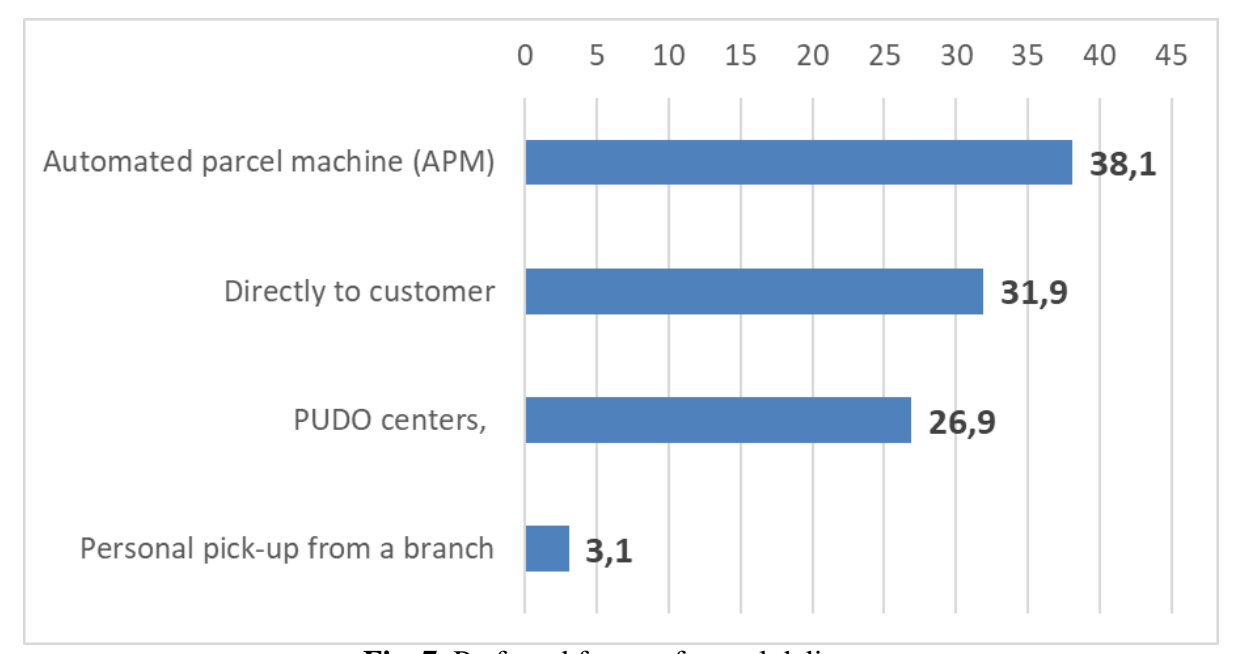

Fig. 7. Preferred forms of parcel delivery

Source: compiled on the basis of own research

By far the most popular form of parcel delivery in the difficult times of the epidemic appeared to be APMs. This option was selected by $38.1 \%$ of the respondents. APMs allow for observance of relatively high sanitary regime rules. Package machines were followed by deliveries directly to the customer (31.9\%). These, however, are often completed without the need to contact the customer in person. The courier may signal his arrival by the door using a doorbell. Furthermore, customers highly value when couriers wear masks and gloves. Another frequently selected form of delivery was PUDO (26.9). The relatively rarest type of delivery was through a visit at a branch of a courier company (only $3.1 \%$ ).

The last mile is one the key stages of an online order completion, because it signifies the first contact with the product. If it is a courier who delivers a parcel, he is often treated as a representative of the seller. The last mile is a critical element of the supply chain in the e-commerce (Lou et al., 2020; Wang et al., 2020).

All preceding processes are often automated and less prone to mistakes. The key to a successful parcel delivery is good communication with the recipient and the application of effective logistics solutions ( Gevaers et al., 2014). 
The respondents also assessed the importance of the sustainable development aspects used in the activities of courier companies.

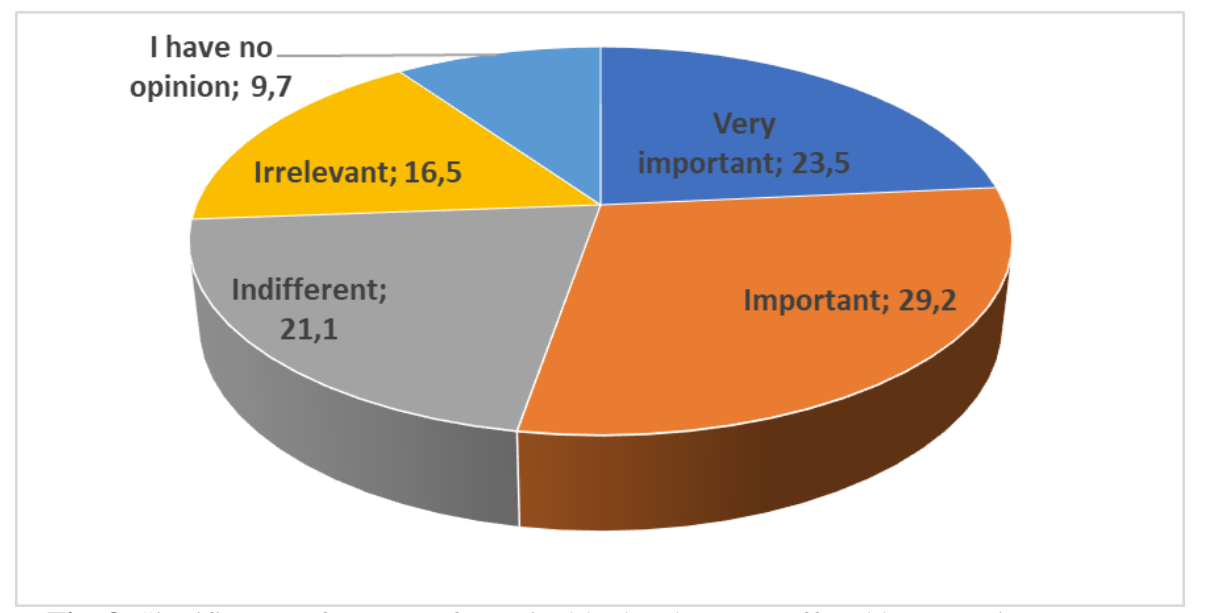

Fig. 8. Significance of aspects of sustainable development offered by a courier company Source: compiled on the basis of own research

The analysis of the data contained in Figure 8 shows that for $29.2 \%$ of respondents the issues of sustainable development are important and for $23.5 \%$ very important. It proves the growing ecological awareness of the society (Tvaronavičienè, Černevičiūtè, 2015; Tseng, Wu, Lim \& Wong, 2019). For only $21.1 \%$ of respondents, matters related to ecology are indifferent or irrelevant (16.5\%). 9.7\% of respondents did not have an opinion on this matter.

Ecology is more and more important for the management of courier companies. Hence the widespread pursuit of solutions that focus on environmental protection. For example, DB Schenker encourages the use of an ecological calculator showing $\mathrm{CO} 2$ emissions to the atmosphere during standard transports, depending on the number of kilometers or the weight of the load. At UPS, the customer can request a service that transports their goods in a hybrid or electric vehicle. In turn, DHL has introduced the GoGreen program, on the basis of which individual routes of the most popular shipments are forested by the company. The company also focuses on the transport of parcels, on a fleet of electric vehicles. Customers who decide to use eco-shipping are rewarded by DHL with a special certificate.

\section{Conclusions}

The conducted study demonstrates that the prime motives behind the choice of a courier company are delivery completion time, service prices, and safety concerns. The last issue has been particularly crucial amidst the Covid19 coronavirus epidemic. Among the individual elements of customer services, flexibility and reliability of deliveries received the highest ratings from courier service users. Over a half of the respondents also highly rated the delivery completion time. Over three-fourths of the studied subjects $(75.8 \%)$ said they felt safe in contact with courier operators. Courier companies were fast and effective to introduce the basic rules of safe customer contact. For nearly every fifth person $(19.3 \%)$, the epidemic-related threats sensed by the respondents were high but possible to accept.

The Polish customer values the freedom to choose a convenient delivery method and fast services. The major reasons are e-commerce development and an increasing number of pick-up points and offers promoting such shipment type. Next, the door-to-door (D2D) segment is gradually absorbed by PUDO and automated package 


\section{ENTREPRENEURSHIP AND SUSTAINABILITY ISSUES}

ISSN 2345-0282 (online) http://jssidoi.org/jesi/ 2021 Volume 9 Number 1 (September)

http://doi.org/10.9770/jesi.2021.9.1(11)

machines. PUDO points are convenient for both customers and couriers. More than one package can be delivered to a selected address and PUDO is accessible 24/7. Therefore, the numbers of undelivered packages because of an absent recipient are dropping. This may, as a consequence, lower the cost of the last mile and increase customer satisfaction.

In the coming years, click\&collect services are said to be on the rise. The digital revolution will have an effect on consumer behavior, which together with the growth of costs of traditional deliveries will stimulate parcel collection at PUDOs. The quantitative share of parcel deliveries completed by PUDOs and automated package machines will be growing faster than their value due to lower prices of delivery to PUDOs than in the D2D system. The major development stimulus in the courier service sector over the years to come will continue to be e-commerce. Moreover, the service which allows customers to manage their parcels at the last mile stage will become something ordinary. This will have a direct effect on the growth of quality standards of customer services.

An important element in the activities of courier companies are also aspects of sustainable development. It is about reducing the negative impact on the natural environment. For over half of the respondents (52.7\%), ecological aspects are important or very important. As a result, the most modern companies invest in such vehicles, the emission of which is as low as possible. These are hybrid and electric cars. Some of the courier companies are heavily involved in creating procedures that optimize the routes of their couriers to their clients. This reduces the time it takes for shipments to arrive, but also lowers fuel or energy consumption. Appropriate GPS systems integrated with systems informing about traffic in particular areas of the city help in this. It translates not only into a better reputation of the company, but is also associated with corporate social responsibility.

It is to be hoped that the analysis of issues related to the management of customer service quality in the courier services market will allow, at least partially, to fill the existing gap in the literature. The aspects related to security in the delivery of parcels to the customer, introduced in the era of the Covid 19 epidemic, should be permanently included in the strategies of courier companies. This will minimize the risk of threats and will be the basis for building appropriate relationships with the customer.

\section{References}

Alsaad, A., \& Taamneh, A. (2019). The effect of international pressures on the cross-national diffusion of business-to-business e-commerce. Technology in Society, 59, 101158. https://doi.org/https://doi.org/10.1016/j.techsoc.2019.101158

Barlow, J. \& Stewart, P. (2014). Markowa obsługa klientów. (Branded customer service). Warszawa: Oficyna Wolters Kluwer

Długosz, J. (2005). Zarzadzanie logistyczną obsługa klienta. (Logistics management customer service). Poznań: Wyd. Akademii Ekonomicznej w Poznaniu.

Gevaers, R., Van de Voorde, E., \& Vanelslander, T. (2014). Cost Modelling and Simulation of Last-mile Characteristics in an Innovative B2C Supply Chain Environment with Implications on Urban Areas and Cities. Procedia - Social and Behavioral Sciences, $125,398-411$. https://doi.org/https://doi.org/10.1016/j.sbspro.2014.01.1483

Golmohammadi, A., Mattila, A. S., \& Gauri, D. K. (2020). Negative online reviews and consumers' service consumption. Journal of Business Research, 116, 27-36. https://doi.org/https://doi.org/10.1016/j.jbusres.2020.05.004

He, P., Zhang, S., \& He, C. (2019). Impacts of logistics resource sharing on B2C E-commerce companies and customers. Electronic Commerce Research and Applications, 34, 100820. https://doi.org/https://doi.org/10.1016/j.elerap.2018.100820

Iwan, S., Kijewska, K., \& Lemke, J. (2016). Analysis of Parcel Lockers' Efficiency as the Last Mile Delivery Solution - The Results of the Research in Poland. Transportation Research Procedia, 12, 644-655. https://doi.org/https://doi.org/10.1016/j.trpro.2016.02.018 


\section{ENTREPRENEURSHIP AND SUSTAINABILITY ISSUES}

ISSN 2345-0282 (online) http://jssidoi.org/jesi/ 2021 Volume 9 Number 1 (September) http://doi.org/10.9770/jesi.2021.9.1(11)

Janjevic, M., \& Winkenbach, M. (2020). Characterizing urban last-mile distribution strategies in mature and emerging e-commerce markets. Transportation Research Part A: Policy and Practice, 133, 164-196. https://doi.org/https://doi.org/10.1016/j.tra.2020.01.003

Kauf, S. \& Tłuczak, A. (2018). Logistyczna obsługa klienta. (Logistic customer service). Warszawa. PWN

Kempny, D. (2001). Logistyczna obsługa klienta. (Logistic customer service). Warszawa, PWE.

Kramarz, M. (2014). Elementy logistyczne obsługi klienta w sieciach dystrybucji. (Logistic elements of customer service in distribution networks). Dyfin Warszawa.

Lemke, J., Iwan, S., \& Korczak, J. (2016). Usability of the Parcel Lockers from the Customer Perspective - The Research in Polish Cities. Transportation Research Procedia, 16, 272-287. https://doi.org/https://doi.org/10.1016/j.trpro.2016.11.027.

Li, X., Zhao, X., Xu, W. (Ato), \& Pu, W. (2020). Measuring ease of use of mobile applications in e-commerce retailing from the perspective of consumer online shopping behaviour patterns. Journal of Retailing and Consumer Services, 55, 102093. https://doi.org/https://doi.org/10.1016/j.jretconser.2020.102093

Liang, C.-C., Liang, W.-Y., \& Tseng, T.-L. (2019). Evaluation of intelligent agents in consumer-to-business e-Commerce. Computer Standards \& Interfaces, 65, 122-131. https://doi.org/https://doi.org/10.1016/j.csi.2019.03.002

Liao, C., Palvia, P., \& Lin, H.-N. (2006). The roles of habit and web site quality in e-commerce. International Journal of Information Management, 26(6), 469-483. https://doi.org/https://doi.org/10.1016/j.ijinfomgt.2006.09.001

Liu, Y., Foscht, T., Eisingerich, A. B., \& Tsai, H.-T. (2018). Strategic management of product and brand extensions: Extending corporate brands in B2B vs. B2C markets. Industrial Marketing Management, 71, 147-159. https://doi.org/https://doi.org/10.1016/j.indmarman.2017.12.016

Lou, Y., Feng, L., He, S., He, Z., \& Zhao, X. (2020). Logistics service outsourcing choices in a retailer-led supply chain. Transportation Research Part E: Logistics and Transportation Review, 141, 101944. https://doi.org/https://doi.org/10.1016/j.tre.2020.101944

Naccache, S., \& Montreuil, B. (2015). Optimizing Consumer Order Delivery Consolidation in Drop-Ship Based B2C Distribution. IFACPapersOnLine, 48(3), 1996-2001. https://doi.org/https://doi.org/10.1016/j.ifacol.2015.06.381

Nadeem, W., Khani, A. H., Schultz, C. D., Adam, N. A., Attar, R. W., \& Hajli, N. (2020). How social presence drives commitment and loyalty with online brand communities? the role of social commerce trust. Journal of Retailing and Consumer Services, 55, 102136. https://doi.org/https://doi.org/10.1016/j.jretconser.2020.102136

Palese, B., \& Usai, A. (2018). The relative importance of service quality dimensions in E-commerce experiences. International Journal of Information Management, 40, 132-140. https://doi.org/https://doi.org/10.1016/j.ijinfomgt.2018.02.001

Patil, H., \& Divekar, B. R. (2014). Inventory Management Challenges for B2C E-commerce Retailers. Procedia Economics and Finance, 11, 561-571. https://doi.org/https://doi.org/10.1016/S2212-5671(14)00221-4

Rita, P., Oliveira, T., \& Farisa, A. (2019). The impact of e-service quality and customer satisfaction on customer behavior in online shopping. Heliyon, 5(10), e02690. https://doi.org/https://doi.org/10.1016/j.heliyon.2019.e02690

Rydzkowski, W. (2011). Usługi logistyczne, Teoria i praktyka. (Logistics services, theory and practice). Biblioteka Logistyka, Poznań.

Schwerdfeger, S., \& Boysen, N. (2020). Optimizing the changing locations of mobile parcel lockers in last-mile distribution. European Journal of Operational Research, 285(3), 1077-1094. https://doi.org/https://doi.org/10.1016/j.ejor.2020.02.033

Shah, P. (2020). Managing customer reactions to brand deletion in B2B and B2C contexts. Journal of Retailing and Consumer Services, 57, 102223. https://doi.org/https://doi.org/10.1016/j.jretconser.2020.102223

Song, P., Zheng, C., Zhang, C., \& Yu, X. (2018). Data analytics and firm performance: An empirical study in an online B2C platform. Information \& Management, 55(5), 633-642. https://doi.org/https://doi.org/10.1016/j.im.2018.01.004

Thirumalai, S., \& Sinha, K. K. (2005). Customer satisfaction with order fulfillment in retail supply chains: implications of product type in electronic B2C transactions. Journal of Operations Management, 23(3), 291-303. https://doi.org/https://doi.org/10.1016/j.jom.2004.10.015 


\section{ENTREPRENEURSHIP AND SUSTAINABILITY ISSUES}

ISSN 2345-0282 (online) http://jssidoi.org/jesi/ 2021 Volume 9 Number 1 (September)

http://doi.org/10.9770/jesi.2021.9.1(11)

Tseng, M.-L., Wu, K.-J., Lim, M. K., \& Wong, W.-P. (2019). Data-driven sustainable supply chain management performance: A hierarchical structure assessment under uncertainties. Journal of Cleaner Production, 227, 760-771. https://doi.org/https://doi.org/10.1016/j.jclepro.2019.04.201

Tvaronavičienė M., Černevičiūtė, J. 2015. Technology transfer phenomenon and its impact on sustainable development. Journal of Security and Sustainability Issues, 5(1), 87-97. http://dx.doi.org/10.9770/jssi.2015.5.1(7)

Vakulenko, Y., Hellström, D., \& Hjort, K. (2018). What's in the parcel locker? Exploring customer value in e-commerce last mile delivery. Journal of Business Research, 88, 421-427. https://doi.org/https://doi.org/10.1016/j.jbusres.2017.11.033

Vinodhini, G., \& Chandrasekaran, R. M. (2014). Measuring the quality of hybrid opinion mining model for e-commerce application. Measurement, 55, 101-109. https://doi.org/https://doi.org/10.1016/j.measurement.2014.04.033

Vrontis, D., Thrassou, A., \& Amirkhanpour, M. (2017). B2C smart retailing: A consumer-focused value-based analysis of interactions and synergies. Technological Forecasting and Social Change, 124, 271-282. https://doi.org/https://doi.org/10.1016/j.techfore.2016.10.064

Wang, Y., Jia, F., Schoenherr, T., Gong, Y., \& Chen, L. (2020). Cross-border e-commerce firms as supply chain integrators: The management of three flows. Industrial Marketing Management, 89, 72-88. https://doi.org/https://doi.org/10.1016/j.indmarman.2019.09.004

Yu, Y., Yu, C., Xu, G., Zhong, R. Y., \& Huang, G. Q. (2020). An operation synchronization model for distribution center in E-commerce logistics service. Advanced Engineering Informatics, 43, 101014. https://doi.org/https://doi.org/10.1016/j.aei.2019.101014

Zhang, Y., Fang, Y., Wei, K.-K., Ramsey, E., McCole, P., \& Chen, H. (2011). Repurchase intention in B2C e-commerce-A relationship quality perspective. Information \& Management, 48(6), 192-200. https://doi.org/https://doi.org/10.1016/j.im.2011.05.003

Zuo, W., Huang, Q., Fan, C., \& Zhang, Z. (2013). Quality management of B2C e-commerce service based on human factors engineering. Electronic Commerce Research and Applications, 12(5), 309-320. https://doi.org/https://doi.org/10.1016/j.elerap.2013.03.005

\section{Acknowledgements}

This research was carried out under the research theme No. 88/20/B financed by a science grant provided by the Ministry of Science and Higher Education of Poland

Adam MARCYSIAK $(\mathrm{PhD})$ is the Doctor of Sciences at Siedlce University of Natural Sciences and Humanities, Faculty of Social Science. Research interests: regional development; sustainability; supply chain management,

ORCID ID: orcid.org/0000-0002-3132-8565

Make your research more visible, join the Twitter account of ENTREPRENEURSHIP AND SUSTAINABILITY ISSUES: @Entrepr69728810

Copyright (C) 2021 by author(s) and VsI Entrepreneurship and Sustainability Center

This work is licensed under the Creative Commons Attribution International License (CC BY).

http://creativecommons.org/licenses/by/4.0/

cC) (i) Open Access 